\title{
Development of agricultural activities in Russia and the Sverdlovsk region in terms of environmental instability
}

\author{
Voronin Boris Aleksandrovich", Chupina Irina Pavlovna, Voronina Yana Viktorovna, and \\ Zarubina Elena Vasilievna
}

Federal State Budgetary Educational Institution of Higher Education "Ural State Agrarian University", Yekaterinburg, Russia,

\begin{abstract}
The model or way of development of the village and rural economy is always associated with the state policy in relation to the rural areas. Since rural areas are not only a place of residence for human capital, but also a place of labor and economic activity of the rural residents, who are initially employed in agriculture, it is natural that the existing agricultural policy has a huge impact on the model or way of the rural development. The model of the existence of the economic entities in the rural areas under the conditions of exclusive state land ownership has ended since 1990. From here, in the 21 st century, the formation of a modern model of Russian agriculture began with organizational and legal forms of management inherent in a market economy.
\end{abstract}

\section{Introduction}

The first five years of modern agricultural reforms have had the most destructive impact over the state of Russian agriculture.

The specified statistical data on the functioning of agricultural production and the food industry in the first years of the XXI century show how the agriculture and the agroindustrial complex can transform in the conditions of an irresponsible agricultural policy, carried out without any connection with the science of management and the foundations of the economy, including the agricultural one.

As a result of this "practically criminal policy", there was not only a denationalization in agriculture, but also the collapse of the relatively stable agricultural production in state and collective farms. As a result, the best arable land and farms were acquired by the investors businessmen, and a significant part of the fields was either sold for cottage settlements or dropped out of agricultural production and overgrown with trees and shrubs, swampy, saline, that is, subjected to degradation.

The number of agricultural organizations was subject to a significant destruction. So, in the Sverdlovsk region as of 01.01.1990, 1,056 state farms, agricultural firms, collective

\footnotetext{
${ }^{*}$ Corresponding author: voroninba@yandex.ru
} 
farms were operable, and as of 01.01.2020, there are just 305 organizations engaged in agricultural production, and some of them are in the bankruptcy proceedings. In addition to agricultural organizations of various forms of management, there are about 750 farms, of which only about a half are engaged in active agricultural production [1].

The average share of farms in the total volume of agricultural production over the past three years is $6 \%$, which is extremely small, taking into account the overall results of the agro-industrial complex of the Sverdlovsk region, both in crop production and in animal husbandry.

\section{Materials and Methods}

The purpose of this study is to analyze the development of the agricultural activities in the context of various models determined by the state agrarian policy.

Methods: historical; sociological; statistical; analysis; synthesis; economic forecasting.

Until 1990, agricultural activities in the Sverdlovsk region had been carried out in 1843 rural settlements with a population of more than 750 thousand people or more than $15 \%$ of the region's population. In 2018, about 690 thousand people already lived in the rural areas, of which, according to statistics, 35 thousand people were employed in organized agriculture.

The modern model of the development of the Russian countryside is associated with a multifunctional rural economy, in which there is traditionally an agrarian economy that develops on the basis of scientific achievements in crop production and in animal husbandry and, in general, the scientific and technical development of agricultural activities.

At the present time, great importance is attached to the selection and seed production of agricultural crops, and to livestock breeding. For 4 natural climatic zones in the Middle Urals, the tasks are to increase the yield of zoned grain crops from today's 20-22.5 centners/ha to 40-50 centners/ha as an average for the region. The experience of achieving such a grain yield is available in the Irbitsky municipal district, in the farms of "Kilachevsky", "Ural" and other agricultural production cooperatives. The task of the management and specialists of agricultural organizations and farmers of the Sverdlovsk region is to introduce this experience in their farms.

In potato and open field vegetable growing, the joint-stock company "Belorechensky" of the Beloyarsk urban district has a great experience in obtaining the heavy yields. The potato yield here (with irrigation) reached 400-500 centners/ha. Vegetables in open ground up to 400 and more centners/ha.

The problem is that the farm purchases seeds of potatoes and vegetables abroad.

Understanding the situation with the import of seeds, a selection and seed production center "Ural Potato" was created in the farm, where domestic potato seeds will be produced not only for the Sverdlovsk region, but also for other entities of the Russian Federation.

In livestock breeding, the milk yield per cow should cross the border of an average of 9 thousand $\mathrm{kg}$ and more. This result requires an increase in the productivity of the milking herd. An important research and production task is to increase the productive longevity of cows.

The Ministry of Agro-Industrial Complex and Consumer Market of the Sverdlovsk Region has developed a concept for the Strategic Development of the Agro-Industrial Complex of the Sverdlovsk Region for the period up to 2035 [3]. 


\section{Results and Discussion}

Based on the actual level of agricultural production in 2018-2019, the level of selfsufficiency for basic food products was: milk and dairy products - $62 \%$; meat and meat products $-57.5 \%$; egg $-97.3 \%$; potatoes $-99.8 \%$; vegetables $-37.5 \%$.

In per capita terms of the Sverdlovsk region, the current indicators look like this: grain $174 \mathrm{~kg}$; milk - $156 \mathrm{~kg}$; meat - $45 \mathrm{~kg}$; potatoes - $137 \mathrm{~kg}$; vegetables - $42 \mathrm{~kg}$; eggs - 339 pieces [2].

As can be seen from the statistical data, the absolute indicators are not high, and if compared with the medical consumption rates, they significantly differ. So, according to the norms per year per person, milk and dairy products should be $340 \mathrm{~kg}$; meat and meat products - 75-80 kg; vegetables - $140 \mathrm{~kg}$; fish - $201 \mathrm{~kg}$. It is not difficult to calculate the volume of agricultural production that must be carried out taking into account the population of the Sverdlovsk region of 4.4 million people.

The production indicators laid down in the Strategy until 2035 do not reach the goal of providing food according to the medical standards, and therefore the implementation of the requirements of the Food Security Doctrine.

If we consider the Sverdlovsk region in terms of the production of ecological agricultural products, then, based on the data of the Green Patrol organization, the region is in the last positions of the ecological rating. In 2019, the Sverdlovsk region is in the last 85 place in the environmental rating of 85 regions. The most polluted city in the region is Nizhniy Tagil. On the territory of the Sverdlovsk region, there are 1,500 industrial enterprises and more than 170 places where metallurgy production wastes are stored. Among the 15 most adverse cities in Russia in terms of the ecological component, Nizhny Tagil and Asbest were included in this number.

Air pollution in the region and in Yekaterinburg is quite high, according to the Hydrometeorological Center, although there is a slight downward trend. The Sverdlovsk region cannot yet improve its performance in terms of water quality. Many industrial enterprises use water bodies to dump their waste. Out of 72 municipalities in the Sverdlovsk Region, 50 municipalities do not have water in accordance with SanPin. By this indicator alone, the region cannot produce environmentally friendly products.

The region's soil suffers from acid rain and industrial and domestic waste. There are 72 cattle cemeteries in the region. This is also an unfavorable situation for the production of pure agricultural products.

The next problem is radiation, which is quite high in the area. Beloyarsk NPP and Ural Electrochemical Plant are located on the territory of the Sverdlovsk Region, where the radioactive background is 7 to 8 times higher.

The main industrial centers, which are focused on hazardous production in the region, are Yekaterinburg, where $21 \%$ of all production falls on heavy metallurgy. In Nizhny Tagil, the most harmful enterprise with an environmental component is Nizhny Tagil Metallurgical Plant, where the Rospotrebnadzor recorded an excess of nitrogen dioxide, ammonia and naphthalene In Asbest, the largest pollutant is the asbestos quarry. People working in this career are at increased risk of various serious illnesses. It is noteworthy that in European countries in 2005, the extraction and use of asbestos were prohibited. Serov is the center of metallurgy and industry.

In addition to this, the problems of agrochemicals are added. On the territory of the Sverdlovsk region, the land was not checked for the concentration of the agrochemicals. Agriculture is conducted here so that everything that is possible is squeezed out of the land. And now the ecologists believe that it will take at least 15 years to clear the soil of chemicals. An interesting fact is that since 1994 the use of agrochemicals has been prohibited. 
But still, one cannot say that there is no struggle for the environment at all in the region. At present, 26 agreements on cooperation between the regional government and large enterprises regarding the environmental protection have been developed. Funds are also allocated for the cleaning of rivers and lakes in the region. Since 2019, the region has been implementing "Preservation of unique water bodies located in the Sverdlovsk region" project. More than one billion rubles will be spent on restoration work to clean up seven water reservoirs and six rivers. In 2019, the bed of the Bobrovka River near the town of Artyomovskiy was cleared. Now they are preparing the Chernoistochinskoye water reservoir near Nizhny Tagil and Lake Shartash for the restoration.

If we take the data for the districts of the Russian Federation, then the largest distribution of the industrial emissions is observed in the Ural Federal District - $31 \%$ of the emissions. The second place is for the Siberian Federal District, where the amount of emissions is $27 \%$. The Volga Federal District is in third place - $15 \%$ of emissions from industrial production. In large cities, this problem is complemented by exhaust emissions. Excess of the norm of exhaust emmisions is observed in 43 Russian cities. And this is only the preliminary data. The problems are also associated with the radioactive soil contamination, which will not allow the production of ecological products on such land. Severe chemical poisoning of soils due to the use of the fertilizers against pests also brought their negative effect.

The economic crisis does not provide any additional funds for agriculture, therefore, agricultural organizations save funds allocated for compliance with the environmental standards.

The most disadvantaged regions in Russia include the Urals, the Murmansk region, the Volga region, western Siberia and the Central region. Krasnodar Territory is also unfavorable in terms of the production of environmentally friendly products. And if you produce organic products on the territory of the Russian Federation, then the North can be attributed to the most prosperous regions. But the climatic conditions of the north are not suitable for crop production. Most of Siberia is also suitable for growing organic agricultural products. The Far East is also the most prosperous.

The problems of the Central Chernozem District are that the agrarians plowed up the meadows, as this area is overpopulated. But this has undermined the fodder base of animal husbandry and further increased the load on the natural landscape. In this district, great importance should be given to measures to protect land and improve soil fertility. A lot of toxic chemicals are stored in rural areas, but not in the special premises. In many occasions, there are no such premises at all. Therefore, they often enter the environment.

In the North-West region, agriculture specializes in the production of dairy products and flax. Flax as a crop depletes the soil. Sowing here cannot be done more than once every seven years. But this is not always observed. To restore the soil, it is better to sow the remaining six years with clover, which restores soil fertility and serves at the same time as feed for the dairy herd.

In the northern region, rivers are polluted by sunken timber and waste from livestock enterprises, and only small plots of land have been developed for agriculture.

In the Volga region, there is quite a bit of natural landscape left. Here, in contrast to the Northern region, the share of plowed land reaches more than $70 \%$. And the problems with water purification are also quite serious here. Petrochemical enterprises on the banks of the Volga disrupt the processes of self-purification of river waters. In the lower reaches, the water in this river is unsuitable even for irrigation. Therefore, the purification of this river is an all-Russian problem. And although agriculture in the Volga region is better developed than in other regions and districts, there is also soil erosion here, there are problems of gullying and degradation of forests. 
Many rivers flow on the territory of the North Caucasian region, but all of them are also polluted. And they are of primary importance in the water supply of the entire region. Many rivers simply dry up here. This is due to sludge, resulting in a loss of flow. For example, the Kuban River, which originates from the ridge of Mount Elbrus, is distinguished by clear water in the upper reaches, but then pollution with clay particles begins. Moreover, the industrial enterprises, due to their waste emissions into the river, relatively pollute it. Vegetation also suffers from this.

The Uralsk region has very low water quality due to river pollution, especially in the Sverdlovsk region. Deforestation in the Urals leads to the destruction of valuable species. Conifers are being replaced by deciduous ones, which are not as valuable. Of course, the region is engaged in artificial afforestation, but these measures are insufficient.

The Far East region is characterized by the same problems that were listed above in other regions. Here red fish are caught and, at the same time, the chemical industry is developing. And industrial waste is also discharged into wastewater. It is this area that provides the country with seafood. Therefore, treatment facilities for water purification are of a primary importance here. So far, the equipment with treatment facilities here is rather weak.

Forest fires can be added to the environmental problems. Floods have also become more frequent lately. It follows from this that it is practically impossible to restore these areas after the fires and floods. And agricultural work on these sites can no longer be carried out.

But there are the enterprises here that pay attention to the environmental component and take measures for this. They upgrade equipment, install purifiers. For example, we shall recall the station in the village of Preobrazhenie and the station in the village of Zarubino, which operate for purification of oily waters and significantly improve the ecological situation in their regions.

Currently, new enterprises are being built, taking into account modern requirements for the environmental safety. An example is the Bureyskaya HPP, which task is to provide electricity to the south of the Far East. This hydroelectric power station should improve not only social, but also environmental conditions, because its project was developed taking into account the minimization of damage to the natural environment. The Bureya water reservoir is also being created, which will not entail the disturbances in the ecological balance. This reservoir will create the conditions for the spread of new species of fish, water birds and mammals in this area.

To improve the environmental component in the country as a whole, and specifically in the Sverdlovsk region, it is necessary to recognize agricultural land and water bodies as protected zones and protect them from industrial waste pollution. It is necessary to prohibit the use of certain types of natural resources. For industrial enterprises, strict waste disposal measures must be introduced. In agriculture, variable soil use must be established to restore certain depleted areas.

\section{Conclusion}

Analysis of the content of the Strategic development of the agro-industrial complex of the Sverdlovsk region for the period up to 2035 allows us to draw conclusions regarding the strategic forecasting of the development of agricultural activities in the Russian Federation, using the example of the Sverdlovsk region.

In the XXI century, a new model of organizations for agricultural activities in Russia is being formed, taking into account scientific and technological innovations, robotization, digital agricultural economy, intellectualization of agricultural production. These scientific and practical areas have the goals of guaranteed food security and independence, as well as the greening of products, a significant impact on minimizing the import of agricultural 
products, raw materials and food, seed and breeding material, veterinary drugs and plant protection products, agricultural machinery and equipment, and successful entering the world agri-food market [5].

Currently, the market for environmentally friendly products, or organic as it is commonly called, is only in the development stage. And although the Institute of Organic Agriculture gives comforting forecasts for the development of environmentally friendly products on the Russian market, its further growth is possible only with the support of the state in relation to farms and personal subsidiary plots. It is the farms and private subsidiary plots that produce organic products.

In order to increase the market for organic products and enter the world market with them, government programs are also needed to support the villagers who produce organic products. Now there is an outflow of rural youth from the village to the city. With the support of the state, the outflow of rural youth will decrease. This will give an additional incentive to produce environmentally friendly products. And in this case it will be quite possible to enter with organic products not only the domestic market, but also the world market.

In order to solve the problems of the Concept of the Development Strategy of the agroindustrial complex of the Sverdlovsk Region for the period up to 2035, assistance will be provided to the implementation of investment projects in the following priority areas:

1) Construction and reconstruction of dairy farming facilities;

2) Construction of pig and poultry facilities;

3) Construction of breeding and genetic centers in animal husbandry (poultry farming);

4) Construction of warehouses for storing vegetables and potatoes;

5) Construction of wholesale distribution centers for storage, processing and marketing of agricultural products and food products;

6) Construction of greenhouse plants for the production of greenhouse vegetables;

7) To increase the production of agricultural products in the crop sector (production of grain, potatoes, vegetables, feed);

8) To organize the purchase and processing of agricultural and wild-growing products from the population, which are the most environmentally friendly.

Priority directions for the development of agricultural production and sales of products are planned to be developed both in municipalities, in which there are rural settlements and developed agricultural production, and in municipalities, in which agricultural production is concentrated mainly in the households [6].

The adoption of the Strategy in itself does not solve the problem of the development of effective agricultural activities by farmers and other subjects of the agro-industrial complex in the current XXI century. Great importance should be attached to the modernization of the management system, as well as the motivation of human resources for highly productive environmental work in agricultural organizations in the context of modern socio-economic transformations associated with geopolitics and geoeconomics.

Currently, the sustainable development of the Russian agro-industrial complex may be influenced by the global financial crisis caused by the coronavirus pandemic, and agricultural producers and agro-industrial complex authorities should be ready for this.

\section{References}

1. Development strategy of the agro-industrial complex of the Sverdlovsk region for the period up to 2035, 386 (2019), http://docs.cntd.ru/

2. A.I. Altukhov, Bulletin of the Kursk State Agricultural Academy, 2, 2 (2014)

3. E.N. Antamoshkina, Bull. Of Volgograd state univ., 1 (20), 187 (2012) 
4. G.V. Bespakhotnyy, Economy of agriculture in Russia, 8, 9 (2013)

5. I.N. Buzdalov, Bulletin of the Institute of Economics of the Russian Academy of Sciences, 2, 7 (2015)

6. R.U. Gusmanov, V.R. Gumerov, Economy of agricultural and processing enterprises, 3, 29 (2015)

7. M.I. Kozyr, Journal of Russian law, 4, 132 (2011)

8. E.V. Stovba, G.S. Mukhametshina, Fundamental research, 8, 156 (2014)

9. Makridakis Spyros G., Forecasting, Planning, and Strategy for the 21st Century, 293 (1990)

10. Ye.V. Stovba, R.N. Masalimov, In the World of Scientific Discoveries, 9.1, 389 (2014) 